\title{
EDITORIAL
}

\section{O ensino de História em combate e as suas conquistas}

\section{The Teaching of History in Combat and its Achievements}

\author{
Para fazer história virai decididamente as costas \\ para o passado e vivei primeiro. Misturai-vos à \\ vida. A vida intelectual, sem dúvida, em toda a \\ sua variedade.
}

Lucien Febvre, Combates pela história

Escrever, pensar e ensinar História é um ato de combate diário, em especial nos últimos tempos. A defesa de uma história plural e pública no Brasil significa luta por visibilidade, respeito e reconhecimento. Estar presente nas páginas dos livros e manuais escolares, ser lembrado nas aulas e ocupar lugares de memórias são atos de coragem de uma pedagogia da história libertadora, inspirada na boniteza do pensamento do nosso inesquecível educador Paulo Freire.

Nós somos professores de História e amamos nosso fazer em diferentes contextos de ensino-aprendizagem. Diariamente milhares de professores e professoras de História, de múltiplas maneiras, empenham-se num combate contra o esquecimento, a ignorância, os quadros de ferro de uma narrativa dura e fria que se apresenta como a "história verdade", a "história oficial", a "história triunfalista" e, para nosso desespero, a apologia à não história. Nossos dias pedem coragem e empenho diante das falas que repudiam e rechaçam o saber histórico na escola e na universidade (e por que não dizer, na sociedade).

Nesse sentido, Paulo Freire sempre enfatizou a necessidade de se ter consciência da importância da atuação docente e dos significados que ela exerce nos estudantes, marcando profundamente sua trajetória escolar e intelectual, bem como sua representação do que seria o ato de educar: 
A responsabilidade do professor, de que às vezes não nos damos conta, é sempre grande. A natureza mesma de sua prática eminentemente formadora sublinha a maneira como a realiza. Sua presença na sala é de tal maneira exemplar que nenhum professor ou professora escapa ao juízo que dele ou dela fazem os alunos, e o pior talvez dos juízos é o que se expressa na "falta" de juízo. O pior juízo é o que considera o professor uma ausência na sala. (Freire, 1987, p. 65)

A sala de aula, além de espaço do saber histórico, do ensinar e aprender, assume a condição de ambiente de "compartilhamento de experiências individuais e coletivas, de relação dos sujeitos com os diferentes saberes envolvidos na produção do saber escolar" (Schmidt; Garcia, 2005, p. 299).

Ao assumir o compromisso público com o ensino de História e na busca de compartilhar reflexões téorico-metodológicas, relatos de pesquisa e experiências práticas em sala de aula, a Revista História Hoje permanece, persiste, resiste. E esperamos a cada número ampliar a presença de profissionais da História dedicados às veredas do ensino por meio de saberes e práticas. Enfim, uma revista de professores/as de História para os/as professores/as de História.

Este número da nossa Revista reconhece esse compromisso com a docência ao trazer o Dossiê "História e Sociedade: o ensino de História a partir de diferentes dinâmicas sociais", organizado por Aparecida Darc de Souza, Rodrigo Ribeiro Paziani e Sérgio Paulo Morais, que apresenta discussões e reflexões sobre o ensino de História a partir dos diferentes sujeitos sociais que dele participam, direta ou indiretamente. Os oito artigos, acompanhados da entrevista com Marcos Silva e da tradução de um ensaio de Michael Merrill e Susan J. Schurman, investem em abordagens que incorporam ao trabalho de reflexão sobre a formação de docentes e a realidade do ensino de História, particularmente daquele que se desenvolve no âmbito da escola, as experiências dos jovens educandos como sujeitos ativos e não apenas compreendidos como meros participantes passivos do processo educativo. A apresentação do Dossiê é um convite, ou melhor, uma provocação a conhecer as suas tramas e histórias.

Neste número trazemos também dois artigos avulsos. Em “A visita técnica como método de ensino para guias de turismo: o Morro da Urca como local de visita e aprendizagem histórica”, José Lúcio Nascimento Júnior (Unisuam/ Seeduc-RJ) parte das categorias produção de sentido, produção de presença e 
consciência histórica como referência para analisar um método de Ensino de História no Curso Técnico em Guia de Turismo. Ao considerar que um professor, para ensinar, recorre a diferentes saberes, e que estes possibilitam o uso de diversos métodos, a escolha da visita técnica como ferramenta de ensino liga-se à possibilidade de junção de dois objetivos no ensino de História para futuros guias de turismo: a aprendizagem histórica e a experimentação do atrativo como local de visita e estudo. O outro artigo, intitulado "Práticas Educativas no Museo Histórico Nacional da Argentina: exposição de memórias e construção de histórias", de Carmem Zeli Gil (UFRGS), toma como foco o trabalho educativo do MHN, desenvolvido com escolas, durante o ano de 2015. Nesse texto, a autora procura refletir sobre as escolhas do museu para efetivar sua proposta educativa no desafio entre expor memórias e instigar a produção de histórias.

A seção "História Hoje na Sala de Aula" traz o artigo "A docência no sistema modular de ensino da rede pública do Pará e a biografia do padre Josimo Moraes Tavares: perspectivas teórico-práticas para a educação histórica", de Moisés Pereira Silva (UEG) e Jôyara Maria Silva de Oliveira (Unifesspa). A finalidade dos autores é pensar a memória da atuação de padre Josimo nos conflitos sociais rurais e conjecturar, na perspectiva da educação histórica, o que os movimentos sociais no campo e o trabalho dos agentes engajados podem ensinar a quem se ocupa do ensino e da aprendizagem da história enquanto disciplina, ministrada no contexto do Araguaia-Tocantins, através do Sistema Modular de Ensino da rede pública estadual de educação paraense.

A seção "Falando de História Hoje" apresenta o artigo "Por um ensino de História que faça sentido: análise das concepções de história de alunos do Ensino Médio", de autoria de Ana Paula Rodrigues Carvalho, doutoranda em História pela UFMT, que discorre acerca dos sentidos da história com base no conceito de consciência histórica de Jörn Rüsen. Nesse estudo, 82 alunos do Ensino Médio da cidade de Guarapuava (PR) foram questionados pela professora a respeito de suas concepções de história. A metodologia empregada utilizou critérios da grounded theory, no que diz respeito a modalidade de recolha e categorização das narrativas. Analisando as narrativas obtidas com jovens, a autora conclui que a concepção de história dos participantes permanece ainda ancorada em uma ideia de história responsável pelo estudo do passado e sem nenhum tipo de vínculo com questões presentes ou futuras. 
Fechando esta edição da Revista História Hoje trazemos a resenha elaborada por Dalânea Cristina Flôr e Claricia Otto, ambas da UFSC, do livro As últimas testemunhas: crianças na Segunda Guerra Mundial, de autoria de Svetlana Aleksiévitch.

Esperamos que os leitores encontrem neste número expectativas e esperanças de futuro para a educação pública, laica, democrática e socialmente situada, tendo sempre o ensino de História como lugar do livre pensar e existir.

Agradecemos a dedicação dos/as organizadores/as do Dossiê e dos/as colaboradores/as deste número que fizeram o aparentemente impossível acontecer de uma forma singular e entusiasmada. Registramos também nossa gratidão aos membros do Conselho Editorial e pareceristas que trabalharam com prazos exíguos neste projeto editorial.

Renilson Rosa Ribeiro

Editor

Cuiabá, dezembro de 2019

\section{REFERÊNCIAS}

FEBVRE, Lucien. Combates pela história. Lisboa: Presença, 1985.

FREIRE, Paulo. Pedagogia do oprimido. 17. ed. São Paulo: Paz e Terra, 1987.

SCHMIDT, Maria Auxiliadora M. dos S.; GARCIA, Tânia Maria F. B. A formação da consciência histórica de alunos e professores e o cotidiano em aulas de História. Cadernos Cedes, Campinas, v. 25, n. 67, p. 297-308, set./dez. 2005. 